\title{
RESPONDING TO THE RELIGIOUS REASONS OF OTHERS: RESONANCE AND NON-REDUCTIVE RELIGIOUS PLURALISM
}

\section{HAJJ MUHAMMAD LEGENHAUSEN}

\author{
The Imam Khomeini Education and Research Institute
}

\begin{abstract}
Call a belief 'non-negotiable' if one cannot abandon the belief without the abandonment of one's religious (or non-religious) perspective. Although non-negotiable beliefs can logically exclude other perspectives, a non-reductive approach to religious pluralism can help to create a space within which the nonnegotiable beliefs of others that contradict one's own non-negotiable beliefs can be appreciated and understood as playing a justificatory role for the other. The appreciation of these beliefs through cognitive resonance plays a crucial role to enable the understanding of those who hold other perspectives. Epistemological and spiritual consequences of this claim are explored.
\end{abstract}

\section{INTRODUCTION: NON-REDUCTIVE RELIGIOUS PLURALISM}

In the philosophy of religion, the phrase 'religious pluralism' is used with a number of definitions that differ both in content and in precision. Just for starters, one may distinguish the following types of religious pluralism: soteriological, normative, epistemological, alethic, and deontological. ${ }^{1}$ In each case, there is some value, respectively: salvation, recognition, knowledge, truth, the fulfilment of religious duties, which are considered by the pluralist to be available to the adherents of a plurality of religious beliefs. Then there are questions about how wide the plurality of religious beliefs to which these values are accorded is taken to extend. There is also a difference between degree pluralisms and equality pluralisms. Equality pluralists claim that all the adherents of any of the faiths included in

\footnotetext{
${ }^{1}$ See Legenhausen (2005); (2006); (2009).
} 
the plurality of denominations over which a type of pluralism is defined are equal with regard to the value that defines that type of pluralism. Finally, we come to the difference between reductive and non-reductive pluralisms. Reductive pluralists claim that there are some common factors among a plurality of religions by virtue of which these religions have the value that defines a type of pluralism. Non-reductive pluralists, to the contrary, claim that the factors that give some value to different traditions may differ from one another.

Over the course of some years, I have defended a form of nonreductive soteriological religious pluralism, ${ }^{2}$ a view inspired by the work of the Shi'ite scholar and martyr Murtađā Mutahhari. ${ }^{3}$ The defence has been both philosophical and theological. Philosophically, there are two arguments, one moral and one based on the implausibility of exclusivist claims. The moral argument is that it is wrong to hold that those outside one's own denomination are bound for eternal damnation because this sort of belief violates moral norms. Norms that favour the recognition of the value of different traditions can also support the claim that what is distinctively valuable in each tradition deserves recognition. The other argument is that the exclusivist belief lacks credibility if it holds that there is a God who is omnibenevolent and omnipotent, but who condemns to perdition those who through no fault of their own do not belong to one's denomination. Furthermore, it may be argued that it is similarly implausible to believe that there is an omnibenevolent omnipotent God who does not recognize the distinctive merits found in different traditions. This argument is related to the theological argument, based on the assumption of principles of Islamic theology, that God is merciful and does what He wills, from which we may conclude that God would not punish people for beliefs for which they are not culpable, and furthermore, that $\mathrm{He}$ could guide different groups of people by what is specific to them, even when such specifics cannot all be combined in a consistent way, and even if we hold that the alternatives to Islam through which He may guide people are in various ways inferior to Islam. The trope of the spiritual path might be adapted to suggest that even those on what we consider to be the wrong path may be guided by markers specific to that path to prevent them from certain kinds of catastrophes.

\footnotetext{
2 This was begun in a series of articles culminating in Legenhausen (1999); and the most recent publication in defence of this view is Legenhausen (2013).

${ }^{3}$ Mutahharī (1978: 352 ff.). (Note that standard diacritical marks for Arabic and Persian words have been altered to facilitate typesetting.)
} 
Philosophically, it may be argued that we should not confine our notion of divine guidance to that which is available only within the confines of a given denomination; and theologically, Muslims should recognize such possibilities of divine guidance, and may consistently do so without compromising claims about the finality and universality of the mission of the Prophet Muhammad (ص). ${ }^{4}$

In what follows, I will consider how to view some epistemological issues concerning religious belief from the perspective of a non-reductive religious pluralism.

\section{NON-REDUCTIVE RELIGIOUS EPISTEMOLOGY: JUSTIFICATION}

Any epistemic value (such as knowledge, certainty, reliability) can be used to generate a form of epistemic religious pluralism according to which the value is to be found across denominational boundaries. I will defend the plausibility of versions of non-reductive epistemic pluralism with regard to epistemic justification, trust, and understanding. Most important is understanding, because it affords a kind of passage across conflicting beliefs through which we can appreciate how beliefs we do not accept function in the doxastic practices of others. My thesis with regard to justification is only that there are some appropriate senses of epistemic justification with respect to which epistemic peers ${ }^{5}$ may belong to different denominations, hold contradictory non-negotiable beliefs, and may be justified in holding these beliefs, despite mutual recognition and availability of evidence. With regard to epistemic trust, I will argue that there are kinds of epistemic trust that we can have in others with whom we have fundamental disagreements.

Sextus Empiricus (c. 160-210) wrote: 'Different people have different and discordant beliefs about the gods, so that neither are all of them to be trusted, because of their inconsistency, nor some of them, because

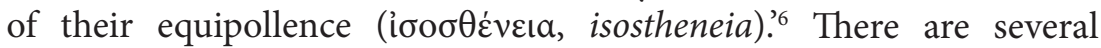
points in this passage that are relevant to contemporary philosophical controversies about religious disagreement: first, contrary to Sextus,

${ }^{4}$ A salutation upon the Prophet Muhammad and his progeny is abbreviated with the Arabic letter: ص.

${ }^{5}$ In what follows, I will say that $S_{1}$ and $S_{2}$ are epistemic peers when neither is significantly inferior to the other with regard to the proper functioning of cognitive faculties and epistemic virtues, including general intelligence, conscientiousness, and logical acumen. See Gelfert (2011).

${ }^{6}$ Adv. Math. bk. IX, 192, cited in Rescher (1985: 224, n. 6). 
some have claimed that the inconsistency among religious views is only apparent; ${ }^{7}$ second, some claim, like Sextus, that the opposition among views leads them to cancel one another out (isostheneia), while others deny this; ${ }^{8}$ and third, there is the issue of trust, whether the parties to sustained disagreement are worthy of trust. ${ }^{9}$

In order to elucidate a non-reductivist position on religious disagreement, it will be instructive to contrast it with the views of Peter van Inwagen. ${ }^{10}$ First, van Inwagen thinks that I am within my 'ethicoepistemic' rights to base my beliefs on incommunicable insights and experience, and to believe that such incommunicables can give one an epistemic edge in philosophical disagreements. It is part of van Inwagen's argument to allow for rational disagreement based on the idea that disputing peers use up their communicable reasons by a mutual disclosure of information, and then differ by the incommunicable part that is left over. It is more likely that they disagree on the evaluation of many pieces of evidence and inferences drawn from them, and that attempts to get to the bottom of these disagreements will only reveal further disagreements. Through the process of dialogue and disagreement, there can occur a modification of positions, even when neither side is willing to consider giving up non-negotiable beliefs. If $S_{1}$ and $S_{2}$ disagree about some set of doctrines, $\Delta$, such that their positions on the truth values of the elements of $\Delta$ are non-negotiable, then although $S_{1}$ and $S_{2}$ will not change their truth value assignments to the members of $\Delta$ after dialogue, they may come to reinterpret some of those elements, and to revise supporting beliefs that fall outside of $\Delta .{ }^{11}$ Giving reasons for our beliefs is not a simple matter of displaying the evidence we have. When we give reasons we construct complex arguments in support of our positions, and in doing so we reflect upon and revise our views of whatever evidence becomes available, including our understanding of why others disagree.

Second, religious beliefs are a complex mix of beliefs about what ought to be done, beliefs about the supernatural, and beliefs about how these various kinds of beliefs and religious practices relate to a community,

${ }^{7}$ See Hick (1989) and Nasr (1985). I criticize these views in Legenhausen (1999).

${ }^{8}$ See Feldman and Warfield (2010), and Jäger and Löffler (2011) and (2012).

${ }^{9}$ See Foley (2001) and Zagzebski (2012).

${ }^{10}$ See van Inwagen (1996).

${ }^{11}$ For a theory of theological reasoning that draws on the notion of a research program as developed by Imre Lakatos, see Murphy (1990) and in Persian, Nasiri (2003). 
and how they serve to put one in relation to God. It is not credible to expect reasonable decisions about what one ought to believe in such matters to be made simply by examination of the implications of some body of evidence, even if the evidence base is expanded to include incommunicable insights. Religious systems of belief, like general political outlooks and comprehensive philosophical views include practical as well as theoretical dimensions, each of which is multifaceted. Such beliefs are justified when they form an integrated worldview that enables one to arrive at explanations and decisions and serve as a framework in which to gain further insight and understanding. ${ }^{12}$ Judging the overall merits of such systems of belief, outlooks, and views can be carried out rather well in different ways, resulting in inconsistencies among the beliefs that are incorporated in different systems.

Third, van Inwagen frames the problem of persistent disagreement as one between two individuals who draw conclusions from shared evidence plus incommunicable insights. However, epistemic attitudes are not justified by inference alone, but through the process of defending one's positions and arguing against alternatives. One does not engage in this process alone. Positions are defended by a large group of people who investigate, research, and make judgments. It may be appropriate for me to take a stand on an issue, with epistemic justification, even though I admit lack of expertise, on the basis of what I have been able to understand, and the trust I have in the work of others.

In sum, I believe that the idea that the proponents of opposing sides of controversial issues can always just sit down and disclose their evidence to one another to reach agreement is a kind of philosophical fantasy. Of course, in some fairly straightforward cases an examination of the evidence might suffice to bring about consensus among those who are rational; but in more complex cases of disagreements in such areas as religion, philosophy, economics, and politics, the way in which one reasons about an issue according to a generally reliable doxastic practice may justify taking a stance other than suspension (or revision) of belief - even though there are others who are at least one's peers and who disagree. ${ }^{13}$

When faced with disagreement, even persistent disagreement, one often looks for more reasons. Reasons are not used up when evidence

\footnotetext{
${ }^{12}$ See Löffler (2006), ch. 5, and Muck (1999: 101-105).

13 See Oppy (2010: 197-198).
} 
is shared. When faced with disputes in the humanities and the natural sciences, we rationally respond to disagreements by trying to find errors and merits, stronger and weaker lines of argumentation, and by reformulating our positions. Sometimes this work leads to a dead end, not only personally, but for the bulk of those engaged in what Lakatos called a 'research programme. ${ }^{14}$ Then the program is abandoned, and belief is suspended until another program is found that seems promising and for which there is good reason to think it will be successful. But as long as the program is advancing, one may have reason to trust its assumptions, even in the face of stiff competition.

What justifies one's beliefs is not just a body of evidence, but also what William Alston has described as good doxastic practice. ${ }^{15}$ When one forms beliefs in accordance with a generally reliable policy, one is justified in holding those beliefs. There is no unique doxastic practice that is recognized as being most reliable. Opposing parties might adhere to doxastic practices that are equally reliable (or which appear to each of them to be most reliable), but which result in the acceptance of beliefs by the parties that cannot be conjoined without contradiction. When we discover that another party is following a reliable practice that yields results that contradict our own, suspension of belief might have disastrous consequences to one's doxastic practice, for since overall reliability is a matter of having a significant proportion of true beliefs as well as the avoidance of error, the policy of suspending belief when faced with peer disagreement might result in a policy that lacks coherence, or that forces us to suppress our natural desire for truth. ${ }^{16}$

An epistemic non-reductive pluralist with regard to the justification of religious belief will hold: first, that there may be epistemic peers with contradictory religious beliefs; second, that the reasons that justify the different beliefs will differ, and even the standards of rationality to which appeal is made in the justification of these beliefs may differ $;{ }^{17}$ and, third, that it may be rational to remain steadfast in one's beliefs despite the recognition of persistent peer disagreement. ${ }^{18}$ To elaborate this position further, we need to consider the issue of trust.

14 See Lakatos (1970). For related discussion see D'Costa (1993) and Enoch (2010: 963).

${ }^{15}$ See Alston (1991), ch. 4.

16 See Zagzebski (2012: 45); and Lam (2011).

${ }^{17}$ See MacIntyre (1988) and D'Costa (1993). 


\section{NON-REDUCTIVE RELIGIOUS EPISTEMOLOGY: TRUST}

At the midpoint of his drama of ideas of 1779, Nathan the Wise (Nathan der Weise), Gotthold Ephraim Lessing presents a discussion about religion between the Sultan, Saladin (Arabic: Salāh al-Dìn), and a Jewish merchant, Nathan. The Sultan asks Nathan how to find the truth about religion. Nathan responds with the famous story of the three rings from the Decameron. In the course of telling the story, the Sultan becomes impatient, and Nathan responds that conflicting religious beliefs are due to different beliefs about history.

Do not all [the religions] ground themselves in history?

Written or transmitted! And

history must indeed be accepted solely on trust and faith? - No? -

Now, in whom do we place our trust and faith with the least doubt? Surely, in our own people?

Those of whose blood we are? ${ }^{19}$

I think that there is something profound in Lessing's reflections, but also something wrong. What is profound is the role that trust plays in religious belief, especially with regard to the acceptance of sacred history. Furthermore, and most urgently for our discussion, with regard to many areas of concern to us, we do not find that those with whom we share blood ties are the least dubious in their opinions. In politics we trust the opinions found in our party more than those of our own fathers and mothers. A non-reductive pluralism about the value of trustworthiness, would emphasize the fact that we often have reason to trust others because of features that are peculiar to them. Indeed, in the normal everyday cases in which we put our trust in others, it is because they have an ability or some knowledge we lack. Likewise, it may be that my self-trust with regard to religious beliefs is not based on trust in the general faculties common to all humanity, but on the particular doxastic practices that I employ in this area. There need be no epistemic presumption in favour of the veridicality of the deliverances of the faculties of other persons on religion, given that they employ very different kinds of doxastic practices, even if in other areas they are

\footnotetext{
${ }^{18}$ See MacIntyre (2009), who argues that a position may be rationally vindicated although intelligent people opposed to the position may remain steadfast in their opposition.
}

${ }^{19}$ Lessing (1779: 132). 
judged to be epistemic peers. The similarity of the general faculties in the self and others may not be sufficient for other's beliefs to yield even a prima facie reason for accepting the other's belief, unless there is reason to think that we are utilizing the same doxastic practices. ${ }^{20}$

Knowing that an astrologer is extremely conscientious in calculating the positions of the planets, and is careful to draw appropriate inferences according to astrological principles will not increase my trust in the predictions of the astrologer, even if the astrologer displays cognitive virtues that (in part) provide me with reason to trust myself. Hence, the cognitive virtues alone do not provide a sufficient ground for trust, but must be coupled with other factors, such as the rejection of principles that are not tenable in the light of modern science or other central elements to one's worldview.

In Linda Zagzebski's treatment of issues related to epistemic authority and trust, she also concludes that people might have reason to trust in the doctrines of their own community rather than in the beliefs of conscientious people of another community on issues over which the communities have differing teachings. Zagzebski takes this to stem from the fact that a person may have reason to trust the community to which they belong more than that of the other person. ${ }^{21}$ This brings us back to the point made by Nathan in Lessing's drama.

Zagzebski contends that when different communities can find shared beliefs, this can serve as a basis for trust between communities. ${ }^{22}$ Here we need to distinguish between trusting in a community because we are epistemically justified in thinking that they have true beliefs and trusting in a community for practical reasons, e.g., because the community will provide a good social environment for us. The fact that a community provides a healthy social environment for its members due to human experiences, moral qualities, and background beliefs that are shared with my community does not give me reason to trust that the other community would provide a good social environment for me. So, similar practical goals can be used to justify conflicting allegiances. Likewise, even if epistemic virtues and powers are exhibited by two communities equally, I may have reason to believe that one community's beliefs are true on matters over which they disagree. Trusting in the virtues and

\footnotetext{
${ }^{20}$ See Zagzebski (2012: 214).

${ }^{21}$ See Zagzebski (2012: 221-228).

22 Zagzebski (2012: 222).
} 
talents of one side in a dispute when the virtues and talents are displayed on the other side as well may be practically justified, but it will not necessarily provide epistemic justification or practical justification for accepting a belief. For epistemic justification, there is no other recourse but to engage in the practice of examining the reasons that can be offered in support of one's beliefs. But the recognition of intellectual honesty and ability in another community may provide epistemic justification for yet another kind of epistemic trust: trust that the other community will conscientiously employ its own doxastic practices. We may thus find (at least) three ways in which a community may be trusted: (1) one may trust a community to come up with true beliefs; (2) one may trust a community in some practical affairs, e.g., to issue honest statements, to provide a secure social environment for its members, to negotiate fairly; (3) one may trust a community to employ its own doxastic practices in a reflectively conscientious manner. Trusting a community in any of these ways may be either practically or epistemically justified. We might have good evidence for trustworthiness of a community in any of these senses; or we may find moral or political reasons for extending one or more types of trust.

The non-reductive point to be made here is that we need not trust others only on the basis of finding in the others that which gives us reason to trust ourselves. For example, I might trust the literature on alienation written by Marxists to provide a kind of guide to the relevant issues and debates, even if I do not accept the major conclusions Marxists draw from these discussions, reject the main philosophical principles on which the analysis is based, and even while I hope to find a better view of the issue that is consistent with Islamic traditions of thinking.

Faced with peer disagreement, Zagzebski offers several reasons for engaging with other communities: Through such engagement we may become aware of errors; presuppositions may come to be recognized; reasons may be considered of which one was unaware, or of whose significance one was unaware. All of this seems to be beyond dispute. What is disputable, however, is the foremost reason that Zagzebski gives for engaging with those with whom we disagree, which she describes as a rational principle:

Need to Resolve Conflict Principle:

It is a demand of rationality for a community to attempt to resolve putative conflicts between its beliefs and the beliefs of other communities. $^{23}$ 
While there are a number of very good reasons for engaging with other communities with which we disagree, this Need to Resolve Conflict Principle is dubious. It is extremely unlikely that our various religious communities are ever going to agree on all their religious beliefs. Given that we are not going to come to any such agreement, there can be no demand of rationality to achieve it.

In the field of conflict studies, which concerns itself with practical social and political conflicts, especially armed conflicts, and not logical or epistemological conflicts, the Mennonite scholar John Paul Lederach has developed a theory of conflict transformation ${ }^{24}$ whose arguments may, with suitable adjustments, be a source for insights in the epistemology of disagreement. Just as the parties to a political conflict might have good reason to remain steadfast in their commitments to their value systems, even when this results in conflict, likewise, given that we operate with different doxastic practices that may be fairly reliable overall, so that reliance on these practices is epistemically justified, rationality cannot demand that the parties to the conflict give up their commitments by withholding belief on disputed issues, or by accommodation or compromise.

Lederach argues that there are cases in which parties to a social conflict are not prepared to withdraw their claims, and they may feel that doing so would amount to abandoning legitimate demands. This leads to suspicion that attempts at conflict resolution would result in injustice. Conflict transformation is proposed as a strategy for recognizing that a conflict is not going to disappear while transforming it in such a manner that it becomes less harmful. Likewise, in cases of philosophical conflicts of beliefs, it may be that neither side could abandon its basic stances without destroying the philosophical doxastic practices each had developed. The philosophical conflict may be considered to be harmful when each side can do little more than undermine the doxastic practices of the other. What the parties to a scientific dispute can do, however, and what they are professionally and rationally obliged to do, is to consider the arguments and refine their positions in response. As Lederach explains, a transformational approach allows us to see conflict as an opportunity for constructive change. So, the members of one community might learn to trust members of another community as conscientious critics

${ }^{23}$ Zagzebski (2012: 224).

${ }^{24}$ See Lederach (2003). 
and partners in constructive dialogue, even when the partners to the dialogue know in advance that fundamental disagreements will remain.

\section{NON-REDUCTIVE RELIGIOUS EPISTEMOLOGY: UNDERSTANDING}

Understanding, like justification, is not merely being in the possession of information, but it requires the ability to respond appropriately to questions about what is understood, especially when the questions are unexpected. Understanding a position or a view implies knowing how the position or view is to be applied in various circumstances, and knowing its strengths and weaknesses. I am concerned with the nonfactive sense of understanding, which is the kind of understanding that can occur when one understands things that may or may not be true, and about which one might not have any belief. ${ }^{25}$ So, one might understand a proposition, say, some formulation of the principle of sufficient reason, or a theory, such as Cartesian dualism, without subscribing to them. In Iran, it is often said that Shahid Mutahhari understood Marxism better than most Marxists.

Nonfactive understanding provides a way of overcoming the logical exclusion of contradictory beliefs in the sense that I can understand different positions that are not consistent with one another. Given several rival theories that are pairwise inconsistent, I can understand all of them while believing in at most one of them.

One can believe with insufficient justification or with insufficient understanding. A tendency to either is an epistemic vice. One who tends to believe without sufficient justification is deficient in rationality; one who tends to believe without sufficient understanding is deficient in wisdom. Wisdom presupposes rationality; but one may be rational without being very wise.

Both rationality and wisdom come in degrees. Beliefs are held more rationally when they are better supported by reasons that justify them and when there is greater integrity in the worldview of which they are a part. Religious views are held with greater wisdom when one has a deeper understanding of the creed and religious laws one accepts.

Justification and understanding are both epistemic values, and both of them are directed toward truth (even nonfactive understanding). I seek to have well justified beliefs in order to avoid error and to raise the likelihood that my beliefs will be true. I seek to understand theories, texts, people

${ }^{25}$ For more on factive and nonfactive types of understanding, see Elgin (2007), Elgin (2009), and Kvanvig's replies to Elgin in Haddock et al (2009: 342-343). 
and events in order to avoid making errors about them, coming to have false beliefs about them, and in order to arrive at truths related to them. If I want to understand Marxism, I seek to gain a true understanding of this philosophical and social movement, but it is not necessary for me to take Marxist theory as providing a true account of surplus value or that I give any practical allegiance to the social movement.

Despite the shortcomings that understanding without acceptance or belief may have, it provides the sole instrument capable of overcoming the barriers that arise between two people or two communities that hold nonnegotiable conflicting beliefs. Of course, there are other ways to overcome barriers, such as personal friendships. However, understanding provides the sole rational means to achieving an epistemological appreciation of the justifiability of the beliefs of others that are in contradiction with our own. Furthermore, even practical means, such as friendship, require understanding if they are to achieve cognitive depth.

Understanding takes place through dialogue, according to Gadamer. The emphasis on dialogue can help us to bring out the contrast between justification and understanding. In dialogue for justification, we seek to defend our own views and to defeat views that are inconsistent with our own by showing that our views have better rational support than their rivals. In dialogue for understanding, we seek to explore how others think about issues and to reveal to others the ways in which we reason about them. In dialogue of justification, we seek to identify agreed standards to which appeal can be made in contesting our views. In dialogue of understanding, we seek to identify common ground, or areas of agreement, in order to provide entry to alien territory. Both kinds of dialogue involve risk. In dialogue of justification, there is the risk of defeat, of losing the debate. In dialogue of understanding, the risk is that one will change in ways that are not expected, and perhaps are undesired. The changes will involve either or both one's understanding of the other and one's self-understanding.

One can only engage in the enterprise of seeking understanding through dialogue by relying on one's own epistemic situation, one's relation to intellectual traditions, and one's presumptions and prejudices. One does not arrive at understanding merely by deriving conclusions based on presumptions and evidence, however, but by engaging in the dialogic practice of seeking and offering reasons and criticisms. One of the most prominent themes in Gadamer's hermeneutics is that the particular standpoint or horizon (Horizont) from which one attempts 
to gain understanding, including one's prejudices, is not merely a factor that limits understanding, but is the means by which understanding is gained. Through dialogue, one may seek to gain understanding of another person's religious views; and in the course of this dialogue, one will also come to identify one's own prejudices and reform them when they are found to lead to distortions. Hence, in seeking to understand others, we must be ready to gain new understanding of ourselves. Although there is no escape from one's horizon, horizons are not static, but change in response to dialogue. Gadamer speaks of understanding as a 'fusion of horizons' (Horizontverschmelzung) or a 'transposing' of ourselves. ${ }^{26}$

Gadamer rejects any analysis of understanding in terms of empathy because he considers this to be limited to a first-personal psychological phenomenon. In her work on empathy, however, Edith Stein was careful to reject any purely psychological view of empathy. ${ }^{27}$ For her, the problem of empathy was essentially epistemological. Stein maintains that in empathetic understanding, it is not necessary for one to have the feelings one understands in another. She begins with Husserl's recognition of empathy as the basis of all intersubjective experience, and explores the conditions that make empathy possible. She considers the dialogical nature of empathy as a process through which we may learn to understand ourselves as we seek to understand others, while admitting, with Scheler, that errors may occur in the process leading not only to misunderstandings of others but also of the self. Our efforts to avoid errors in self-understanding and the understanding of others requires us to continually shift perspectives from our own first-person standpoint to that of how we are perceived by others. ${ }^{28}$

Our task, however, is to attempt to understand the kinds of reasons that the followers of other religions have for their beliefs, especially when these beliefs logically exclude our own beliefs. For this project, considerations of empathy can only provide some clues, for we are concerned not so much with feelings but with reasons. At the same time, the language employed by Gadamer of the 'fusion of horizons' requires agreement, while our problem is how to reach understanding when there is intractable disagreement. Gadamer does not tell us how horizons can be fused when they have non-negotiable contradictory contents.

${ }^{26}$ Gadamer (2004: 304); Gadamer (1990: 310).

27 Stein (2008: 33-35); Stein (1989: 21-22).

${ }^{28}$ See MacIntyre (2006: 83-85). 


\section{NON-REDUCTIVE RELIGIOUS EPISTEMOLOGY: RESONANCE}

If two communities forge their identities with reference to conflicting non-negotiable intractable beliefs, must they be unintelligible to one another? If their beliefs are justified according to divergent standards and doxastic practices, does it become impossible to reach any understanding? In this section, I will sketch the optimistic defence of negative answers to these questions. The suggestions are presented through the metaphor of resonance.

Resonance is the opposite of dissonance. The notion of cognitive dissonance was introduced in psychology by Leon Festinger in the 1950s, who argued that people use various mechanisms in order to avoid or attenuate internal psychological conflicts. ${ }^{29}$ Festinger's notion of dissonance included conflicts between feelings and beliefs, and not merely formal contradictions, and if we are to understand the beliefs of others, the emotional associations of the beliefs cannot be overlooked. By resonance, however, I do not intend a mere absence of dissonance. In ordinary language we say that certain kinds of advertisement resonate with customers and motivate them to make purchases. What is meant is not merely the removal of psychological obstacles but the arousing of a kind of acceptance that the customer feels toward the salesperson or the advertising message. The sales pitch is welcomed, both cognitively and emotionally.

Resonance need not be of the sort at which advertising aims. Acoustic resonance can be confined to a limited space. Each room is said to have its own resonant frequencies. A driving force of a resonant frequency can produce sustained high amplitude oscillations. Understanding occurs through dialogue when the conversation is able to produce sustained exchanges in which the parties to the dialogue are able to gain knowledge (or justified beliefs) about the topic of discussion, about their dialogue partners, and about themselves. In the process of such exchanges, opportunities for developing trust between the participants emerge. Regardless of the question of justification, resonance is needed for understanding. Resonance can be emotional or cognitive or both. Here I am concerned with cognitive resonance, or with the cognitive aspect of a phenomenon of resonance in which cognitive and emotional elements are inseparable.

${ }^{29}$ Festinger (1957). 
Stein's discussions of shifting one's perspective ${ }^{30}$ may be interpreted as special kind of a more general type of phenomenon of compartmentalization. We are able to compartmentalize our beliefs so as to have good discussions with teachers about the topics they teach, regardless of the differences we may have with them about politics or religion. The integration of what the student has learned with the rest of the student's network of beliefs and commitments is left to the student. Compartmentalization serves as a tool by means of which we can make use of inconsistent beliefs in our reasoning without incoherence: Inconsistent beliefs are relativized to their own compartments or perspectives. The American philosopher, Wilfrid Sellars, proposes this sort of strategy in response to the inconsistency he finds between what he calls 'the manifest image' and 'the scientific image'. Sellars suggests that although our ordinary pre-scientific view of the sensible world is inconsistent with the picture of the world that modern physics draws for us, we can bring the two together, not by immediately forging a 'synoptic vision', but through the coordination of our intentions. ${ }^{31}$ Exactly how this is to be done, and whether it results in a kind of relativism are left unclear in Sellars' writings. Regardless of how these issues are to be sorted out, the strategy of compartmentalization and subsequent attempts at a stereoscopic view may prove practically valuable techniques in the pursuit of understanding.

Sometimes we gain theoretical expertise without subscribing to the theories we learn. One who rejects logical intuitionism may nevertheless gain an expertise in intuitionist systems of logic. There have been Orientalists who have gained a profound knowledge of Islam without becoming Muslims. Some of these Orientalists have gone much further than just gathering an enormous amount of information about Islam. Likewise, I know Muslims who have let the beliefs of Christian communities resonate with them without converting to Christianity or taking on an eclectic set of beliefs.

As Stein points out, one can empathize with the feeling of joy expressed by one's brother even though one does not have that feeling oneself, but one imagines how the brother feels; and this may even happen while one's own feelings are quite contrary to those with which one empathizes. So, I might feel annoyed at seeing our mother on a particular occasion,

\footnotetext{
${ }^{30}$ Stein (2008: 80-81); Stein (1989: 61-63).

${ }^{31}$ See Sellars (1971), ch. 1.
} 
although that does not prevent me from empathizing with my brother's joy at seeing her. Something similar can happen at a more intellectual level. One may gain an appreciation of how a Marxist thinks about religion, even while maintaining that the Marxist view of religion is fundamentally flawed. I can allow the Marxist view to resonate within me, without accepting the view as my own. I can learn how Marxist views on religion fit into the bigger picture of Marxist philosophy and politics. I can even get to the point of knowing how Marxist views on religion may develop in the face of new challenges. I can come to appreciate how the view fits in Marxist doxastic practices.

While justified beliefs are necessary for knowledge, resonance is necessary for depth of understanding. Greater cognitive resonance makes for deeper understanding. Needless to say, resonance can be illusory. We can think that we know exactly how someone thinks about an issue, and be able to predict how the person will respond to some questions, but yet fail to correctly see how the beliefs in question fit into the other's worldview. So, just as there can be justified beliefs that turn out to be false, there can be cognitive resonance that accompanies misunderstanding.

A certain kind of parochialism occurs when we do not allow the beliefs of other groups to resonate with us. We refuse to understand them. Sometimes it is through a wilful stubbornness, but sometimes it is just innocent inability. We simply are unable to devote the time and energy needed to understand every group that seems to have members who are our epistemic peers but with whom we disagree. Part of understanding another is knowing what to expect, how they will respond and why. With some people, I draw a blank. Epistemic resonance is a kind of filling in the blank. One learns how the other reasons.

If my rejection of another belief is to have the fullest justification possible, and that belief is held by those whom I take to be epistemic peers, I will need to let their beliefs resonate with me before I can be sure that there is nothing in the view that I have rejected that would enable those who hold it to respond effectively to whatever objections I have to it. But achieving maximal justification is not the most important reason for seeking to let the beliefs of others resonate. We miss opportunities for self-understanding and for understanding others when we are focusing exclusively on where we agree and differ in our beliefs, and on debating strategies. Understanding is to be won through resonance, and not 
merely by the elimination of conflicting beliefs. Indeed, in the absence of resonance misunderstanding can persist despite agreement.

In order for there to be successful resonance with a view, one must learn to navigate the space of reasons in the manner of those who are one's epistemic peers and who hold the view, that is, one must learn how they would judge cases and apply their view to various kinds of dialogue. One must learn what sorts of questions to ask, and how to respond to the questions and objections of others. This is not a matter of sharing feelings or beliefs. Navigational skills in foreign intellectual waters cannot be achieved by even the most sensitive kinds of empathy, for one can empathize with another's religious commitment, but be completely at a loss with regard to the other's theological position.

There are various strategies that might be employed in order to achieve cognitive resonance with the views of a group whose beliefs one does not share. First, one can imagine that one holds other beliefs. Even though I am not a Calvinist, for example, I can learn about Calvinism and use my powers of imagination to envision myself as a Calvinist. One can engage in various kinds of fictionalist strategies for the purpose of gaining understanding. Here, I will mention only two. First, I could pretend to be a Calvinist, but not to deceive anyone. I could tell my Calvinist friends that I was going to pretend to be a Calvinist in order to get to understand their theology so that I could pass an exam in religious studies, for instance. Second, I could suppress my true beliefs though a kind of mentalis restrictio or mental reservation. Mental reservation was a way to mitigate lying in situations in which the lie was justified by mentally adding words to what is spoken aloud so that the complete statement would be true, although what is heard would be untrue. As a strategy for resonance, the purpose is not to deceive, but to learn to reason as others do, when the others' reasoning is based on premises one rejects. So, instead of pretending to believe as Calvinists do, when I want to try to reason along with Calvinists, I could mentally preface my claims with 'If I were a Calvinist, I would believe that ...' or some such conditional.

An important technique for learning to resonate with views that conflict with our own is to begin with beliefs that we share with the others whom we seek to understand. The shared beliefs can serve as a basis from which we can begin to develop an appreciation of how another view may be imagined with its own integrity, different from one's own, yet sharing significant beliefs. Once a set of common or shared beliefs is identified, 
the process of learning to resonate with the beliefs of others can take various forms. At one extreme, one can put aside or bracket one's own beliefs that fall outside the common set, and try to imagine how that set could be expanded in a reasonable way to yield the complete belief set of one's dialogue partner. Call this strategy bracketing. At the other extreme, one might attempt to attribute as many of one's own beliefs to the dialogue partner as possible and revise one's view of the partner only as needed to maintain integrity. Call this strategy projection and revision. Either of these methods, or a combination of them, is employed in ordinary conditions of attempting to learn about a view that we are not prepared to accept. Thus, if I want to learn to understand intuitionist logic, I will first identify the kinds of inference and axioms that intuitionist logic shares with the standard logic that I accept. Next, I will try to learn how the exclusively intuitionist beliefs can make sense in terms of the shared beliefs to form a consistent belief set. To gain a deeper understanding of how new forms of intuitionist logic may be developed, I will either draw upon my own previous beliefs to the extent that they can be adapted to the intuitionist views, or I will ignore my own previous beliefs and try to find other forms of intuitionist reasoning solely on the basis of what I have learned about intuitionism.

Using the bracketing strategy, I might imagine myself as an intuitionist, either through pretending or by mental reservation. Using the projection and revision strategy, I could imagine what it would take for me to actually become an intuitionist, how I could integrate intuitionist beliefs into my own belief set.

This process of learning to resonate with the views of another can achieve any of various degrees of success. In some cases, the success may be minimal. We may find ourselves to be incapable of understanding the other's view. I would not attempt to defend the view that resonance with views that we do not accept is necessary in order to be justified in rejecting them, although the highest degree of justification for the rejection of at least some views will require the kind of deep understanding of them that occurs when one allows oneself to resonate with them. Furthermore, in order to engage in dialogue with others whose beliefs I reject in a way that is conducive to mutual understanding, resonance will be necessary. By allowing resonance and deepening it, I can find truth, even in views that I reject - not that I will accept the view I reject as true, but I may find that the view includes truths in addition to the beliefs I consider to be incorrect. More importantly, by learning to use alien doxastic practices, 
I may find ways in which to integrate aspects of these practices in my own in a coherent and fruitful manner.

\section{NON-REDUCTIVE RELIGIOUS EPISTEMOLOGY: SCRIPTURAL REASONING}

In the early 1990s, scholars of modern Jewish philosophy and Rabbinic texts began to meet together to develop an interdisciplinary approach to key questions about Judaism. The academic meetings that were held and their university forums, as well as the practice of study that evolved, came to be known as Textual Reasoning. In the mid-1990s, some Christian colleagues were invited to observe, and they suggested that the practice could serve as a model for interfaith dialogue. Later, Muslim scholars were also invited, and the result was dubbed 'Scriptural Reasoning' by Rabbi Peter Ochs. ${ }^{32}$ The movement (commonly referred to as 'SR') has since sprouted various branches and Ochs also has founded an academic journal with the same name. ${ }^{33}$ Scriptural Reasoning is a practice guided by views of mutual respect and the desire to understand others that resonates with non-reductive religious pluralism, particularly with regard to epistemological concerns, including the recognition of intractable differences and the promotion of wisdom and depth of understanding by learning how religious believers undertake the practices of reasoning about and on the basis of their scriptures in their own ways.

Other forms of dialogue continue to take place that focus on theology or philosophy instead of scripture, but that share in much of the nonreductive ethos of mutual respect and efforts to gain wisdom through the deeper understanding of the views of others. Most of these encounters have been between the adherents of different faith communities; but, in principle the general aims of mutual understanding and wisdom through the respectful attempt to learn the doxastic practices others use when they reason could be applied to groups and individuals beyond the Abrahamic tent.

In an interview in Qom, Ayatullah Ka $\mathrm{Cbi}^{34}$ has interpreted the following verse of the Qur'an in an inclusive way. The verse specifically mentions the People of the Book, but the principle is more general:

\footnotetext{
${ }^{32}$ For an account of the origins of Scriptural Reasoning, see Ford (2006).

${ }^{33}$ The Journal of Scriptural Reasoning, available at: <etext.virginia.edu/journals/ssr/>.

${ }^{34}$ Abbas Kabi Nasab is a former member of the Guardian Council of the Islamic Republic of Iran. He currently holds a seat in the Assembly of Experts.
} 
Muslims are enjoined to find shared beliefs on the basis of which they can enter into dialogue with others.

Say: 'O People of the Book! Come to a common word between us and you, that we worship none but Allah, and that we associate no partners with Him, and that none of us shall take from among ourselves Lords aside from Allah.' Then, if they turn away, say: 'Bear witness that we are Muslims.' (3:64)

We are not to engage with others for the sake of disputing with them, but for dialogue. The shared basis from which we can begin dialogue with other monotheists is a commitment to the principles mentioned in the verse. If we are to engage with non-monotheistic dialogue partners, we should follow the same procedure of inviting them to participate with us in dialogue on the basis of shared commitments, which might be, for example, to strive for justice and the alleviation of oppression. It is important to notice that the 'common word' is only what serves for the invitation and initiation of dialogue.

For the Shi'ah, the need to engage with others on the basis of their own scriptures is found in narrations from the first and the last of the twelve Imams. It is reported that Imam ' $\mathrm{Ali}(\varepsilon)^{35}$ publicly stated:

[By Allah!] ${ }^{36}$ If I were given the cushion [the seat of judgment], ${ }^{37}$ I would judge between the people of the Torah by their Torah, and between the people of the Gospel by their Gospel and between the people of the Qur'an by their Qur'an. ${ }^{38}$

In another narration, it is reported that Imam 'Alī $(\varepsilon)$ said:

If I were given the cushion [the seat of judgment], I would judge between the people of the Qur'an by the Qur'an so that it would glisten for Allah [or radiate to Allah], between the people of the Torah by the Torah so that it would glisten for Allah, between the people of the Gospel by the Gospel so that it would glisten for Allah, and between the people of the Psalms according to the Psalms so that it would glisten for Allah. ${ }^{39}$

35 The Shi'ah abbreviate the Arabic for 'peace be with him' after mentioning the Imams and certain other sacred figures by using the letter: $\varepsilon$.

${ }^{36}$ This phrase is omitted in some reports.

${ }^{37}$ Literally: 'If the cushion were unfolded for me.' The phrase is used to mean being provided with executive/judicial authority.

${ }^{38}$ al-Hilālī (2002: Vol. 2, 803), hadith 32; also Muntazir Qāim (2005: 204-205).

39 al-Safār al-Qummi (1984: 132). In this collection there is an entire chapter consisting of nine narrations similar to this, which is the first of them. 
The narrations similar to these are so numerous that the Shi'ah consider the claim that Imam 'Ali $(\varepsilon)$ said words to this effect, and most likely on more than one occasion, to be mutawätir, that is, it is considered inconceivable that the content of the narration is untrue.

These reports are an important endorsement of the non-reductive perspective for three reasons. First, Imam 'Alī ( $(\varepsilon)$ claims that he would reason on the basis of the different scriptures, so that there is the engagement in reasoning to offer judgment based on each of the scriptures of the religious communities. Second, he is not to reason on the basis only of what is in agreement with the Qur'an, but on the basis of their Torah and their Gospel, that is, on the basis of the scriptures as accepted by their own communities of followers. Third, the fulfilment, blossoming, or radiant glistening of the scriptures is found through his recourse to them to issue judgments among their followers. According to the non-reductive epistemological pluralism I have sought to outline here, the following three corresponding points are to be noted: First, we are to seek understanding with others by learning to engage in their doxastic practices; second, we are not to attempt to reduce the views of others only to what we hold in common with them; and, third, each of the commitments of the faith communities to their scriptures may be found pleasing to God, without any need to claim that divine judgment is indifferent to their points of conflict.

These points receive further support in Shi' $i$ theology on the basis of another set of narrations according to which the Twelfth Imam (ع) will judge between the people of the various scriptures by their scriptures when he emerges from occultation. ${ }^{40}$

The doxastic practices of Jews, Christians, and Muslims include reference to scriptural authority. It is only with respectful regard to and resonance with the cognitive frameworks that arise from these practices and others that we can think of one another as sharing in the understanding and wisdom that make meaningful dialogue and rationality itself possible among us. We do not enter into dialogue with more than a little trust, which we can only pray will blossom and bear fruit if properly cultivated. Our doxastic practices neither need to be compromised by adapting to one another nor do they need to be boiled down to an empty formalism that could be abstracted from all of them; rather we require them to be reconciled by joining them together through

${ }^{40}$ E.g., al-Nu'mānī (2003: 323-324). 
the practical knowledge of how they enable us to reason with members of our own communities and others. ${ }^{41,42}$

\section{BIBLIOGRAPHY}

Alston, William P. 2005. Beyond 'Justification': Dimensions of Epistemic Evaluation (Ithaca: Cornell University Press)

Alston, William P. 1991. Perceiving God: The Epistemology of Religious Experience (Ithaca: Cornell University Press)

D’Costa, Gavin. 1993. 'Whose Objectivity? Which Neutrality? The Doomed Quest for a Neutral Vantage Point from which to Judge Religions', Religious Studies, Vol. 29: 79-95

Elgin, Catherine. 2009. 'Is Understanding Factive?', in Haddock et al (2009), pp. 322-330

Elgin, Catherine. 2007. 'Understanding and the Facts', Philosophical Studies, Vol. 132: $33-42$

Enoch, David. 2010 'Not Just a Truthometer: Taking Oneself Seriously (but not Too Seriously) in Cases of Peer Disagreement', Mind, Vol. 119: 953-997

Feldman, Richard, and Ted A. Warfield, eds. 2010. Disagreement (Oxford: Oxford University Press)

Festinger, Leon. 1957. A Theory of Cognitive Dissonance (Stanford, CA: Stanford University Press)

Foley, Richard. 2001. Intellectual Trust in Oneself and Others (Cambridge: Cambridge University Press)

Ford, David F. 2006. 'An Interfaith Wisdom: Scriptural Reasoning between Jews, Christians and Muslims', Modern Theology, Vol. 22, No. 3: 345-366

Gadamer, Hans-Georg. 1990. Wahrheit und Methode: Grundzüge einer philosophischen Hermeneutik (Tübingen: Mohr Siebeck) (First published in 1960.) Gadamer, Hans-Georg. 2004. Truth and Method: Second, Revised Edition, Joel Weinsheimer and Donald G. Marshall, trans. (London and New York: Continuum)

Gelfert, Axel. 2011. 'Who Is an Epistemic Peer?', Logos \& Episteme, 2 (4): 507-514 Haddock, Adrian, Alan Millar and Duncan Pritchard. 2009. Epistemic Value (Oxford: Oxford University Press)

al-Hilālì, Abū Saādiq Salīm ibn Qays (1423/1381/2002) Kitāb Salīm ibn Qays alHilālī, Muћammad Bāqir al-Anśārī al-Zanjānī, ed., Qom: Dalīl-e mā.

${ }^{41}$ I would like to express my thanks to Hamid Vahid for discussions about the epistemology of peer disagreement and for introducing me to the current debate. Although we disagree on various aspects of the topic, I have learned much from the dialogue.

42 This paper was originally presented in Berlin, at a workshop for the Analytic Theology Project, generously funded by the John Templeton Foundation. 
Hick, John. 1989. An Interpretation of Religion (New Haven: Yale University Press)

Jäger, Christoph, and Winfried Löffler, eds. 2012. Epistemology: Contexts, Values, Disagreement (Heusenstamm: Ontos)

Jäger, Christoph, and Winfried Löffler, eds. 2011. Epistemology: Contexts, Values, Disagreement. Papers of the 34th International Wittgenstein Symposium (Kirchberg am Wechsel: Austrian Ludwig Wittgenstein Society)

Jordan, J. and D. Howard-Snyder, eds. 1996. Faith, Freedom and Rationality (Lanham, MD: Rowman and Littlefield)

Khalil, Mohammad Hassan, ed. 2013, Between Heaven and Hell: Islam, Salvation, and the Fate of Others (Oxford: Oxford University Press)

Lakatos, Imre. 1970. 'Falsification and the Methodology of Scientific Research Programmes', in Lakatos and Musgrave (1970), pp. 91-196

Lakatos, Imre, and Alan Musgrave, eds. 1970. Criticism and the Growth of Knowledge (Cambridge: Cambridge University Press)

Lam, Barry. 2011. 'On the Rationality of Belief-Invariance in Light of Peer Disagreement', Philosophical Review, Vol. 120: 207-245

Lederach, John Paul. 2003. The Little Book of Conflict Transformation (Intercourse, PA: Good Books)

Legenhausen, Hajj Muhammad. 2013. 'Nonreductive Pluralism and Religious Dialogue', in Khalil (2013), pp. 153-179

Legenhausen, Hajj Muhammad. 2009. 'On the Plurality of Religious Pluralisms', International Journal of Hekmat, Vol. 1, available on-line at: $<$ http://peacethroughunderstanding.blogspot.com/2010/05/plurality-ofpluralisms.html $>$ [accessed 12/06/2013]

Legenhausen, Hajj Muhammad. 2006. 'A Muslim's Proposal: Non-Reductive Religious Pluralism, a lecture at the University of Innsbruck, available online at: <http://www.uibk.ac.at/theol/leseraum/texte/626.html> [accessed 12/06/2013]

Legenhausen, Hajj Muhammad. 2005. 'A Muslim's Non-Reductive Religious Pluralism', in Boase (2005), pp. 51-73.

Legenhausen, Hajj Muhammad. 1999. Islam and Religious Pluralism (London: al-Hoda)

Lessing, Gotthold Ephraim. 1779. Nathan der Weise (Berlin: C. F. Voss)

Löffler, Winfried. 2006. Einführung in die Religionsphilosophie (Darmstadt: WBG)

MacIntyre, Alisdair. 2009. 'Intractable Moral Disagreements', in Cunningham (2009), pp. 1-17

MacIntyre, Alisdair. 2009. 2006. Edith Stein: A Philosophical Prologue, 19131922 (Lanham: Rowman \& Littlefield)

MacIntyre, Alisdair. 1988. Whose Justice? Which Rationality? (Notre Dame: University of Notre Dame Press) 
Muck, Otto. 1999. Rationalität und Weltanschauung (Innsbruck-Wien: Tyrolia Verlag)

Muntazir Qäim, Mahdi. 2005. Jesus (Peace be with him) Through the Qur'ān and Shi' ite Narrations, Hajj Muhammad Legenhausen, trans. (New York: Tahrike Tarsile Qur'an)

Murphy, Nancey. 1990. Theology in the Age of Scientific Reasoning (Ithaca: Cornell University Press)

Mutahharī, Murtađā. 1357/1978. 'Adl 'Ilāhī, (Divine Justice), 10th printing (Qom: Intishārāt-e Śadrā)

Nasiri, Mansur. 1382/2003. Raveshshenasi-ye 'ilm va ilahiyat (Methodology of Science and Theology) (Qom: Entesharat-e Mu'assesseh Amuzeshi va Pazhuheshi Imam Khomeini)

Nasr, Seyyed Hossein. 1985. Religion and Religions: The Challenge of Living in the Multireligious World (Charlotte: The University of North Carolina Press) al-Nu'mānī, Ibn Abū Zaynab. 2003. Al-Ghaybah: Occultation, Abdullah alShahin, trans. (Qom: Ansariyan)

Oppy, Graham. 2010. 'Disagreement', International Journal of the Philosophy of Religion, Vol. 68: 183-199

Rescher, Nicholas. 1985. The Strife of Systems (Pittsburgh: University of Pittsburgh Press)

al-Śafār al-Qummī, Muћammad ibn al-Hasan ibn al-Farūkh. 1404/1984. Baśāì al-Darajāt (Qom: Maktab Ayatullah al-'Uźmā al-Maráashī al-Najafī)

Sellars, Wilfrid. 1971. Science, Perception and Reality (London: Routledge \& Kegan Paul)

Stein, Edith. 2008. Zum Problem der Einfühlung (Freiburg im Breisgau: Herder) Stein, Edith. 2008. 1989. On the Problem of Empathy, Waltraut Stein, trans. (Washington, D.C.: ICS Publications)

van Inwagen, Peter. 1996. 'Is it wrong, everywhere, always, and for anyone to believe anything upon insufficient evidence?', in Jordan and Howard-Snyder (1996), pp. 137-153

Zagzebski, Linda T. 2012. Epistemic Authority: A Theory of Trust, Authority, and Autonomy in Belief (Oxford: Oxford University Press) 